\title{
Profiling, Distribution and Information Needs of Farmers' Approaching Pashu Palan Melas
}

\author{
Haneet Kaur, Ankita Singla, Prabhjinder Singh, Aparna, \\ Sandip Shilwant, Snehdeep Singh and Ravneet Kaur* \\ Department of Animal Husbandry, Ludhiana, Punjab, India \\ *Corresponding author
}

\begin{tabular}{l} 
K e y w o r d s \\
$\begin{array}{l}\text { Social demographic, } \\
\text { Livestock fair, } \\
\text { Agriculture }\end{array}$ \\
Article Info \\
$\begin{array}{l}\text { Accepted: } \\
\text { 07 March } 2020 \\
\text { Available Online: } \\
\text { 10 April } 2020\end{array}$ \\
\hline
\end{tabular}

The present study was conducted to assess the social demographic profile, distribution and information needs of farmers visiting the Livestock Fair (Pashu Palan Mela) held at Guru Angad Dev Veterinary and Animal Sciences University (GADVASU), Ludhiana in September, 2019 via structured interview schedule. The study revealed that $34 \%$ of respondents who attended the livestock fair belonged to upto 25 years age group category, with the education level of $64 \%$ farmers upto matriculation or higher secondary. The motive of more than half of the farmers to attend the livestock fair was to gather new information on livestock and agriculture. Moreover, $87 \%$ farmers were interested to come to livestock fair in future, even in the absence of new technology or inventions. The proportion of about $95 \%$ respondents regarded livestock fair as an important means of dissemination of knowledge. In addition, about 58\% farmers were interested to opt livestock related trainings as their future endeavor. The livestock fair was considered to fulfill the purpose of $86 \%$ farmers attending it.

\section{Introduction}

The contribution of livestock in India is about $25.6 \%$ and $4.1 \%$ in Agriculture and National GDP. The milk production in India has touched the mark of 165.4 MT yet the productivity per animal is quite low when compared to developed countries. This low productivity of cattle and buffaloes owned by marginal and small farmers is due to very low or non-adoption of improved production technologies (Triveni, 2016). Timely transfer of knowledge to the farmers plays a crucial role in improvement of livestock economy.

Although animal husbandry practices in India are based on traditional knowledge, yet the rising demand for animal products, complex production technologies, globalization and consumer concerns about food safety have increased the need of information flow to the producers (Mishra et al., 2006; Verbeke, 
2001; Adhiguru et al., 2009). One of the basic contributions in the transfer of technology is the speedy scattering of technological information from the research framework to farmers in the field and collection of farmers' feedback to the information (Subhas et al., 2015).

Agricultural knowledge and related information is the fundamental criterion for increased productivity and development in India as most of the population is involved in agriculture (Das, 2012). Information has been regarded as the fifth need of man after air, water, food and shelter by Kemp (Bachhav, 2012). The higher exposure of farmers to information sources enhances the possibilities of adoption of innovative technologies and scientific management practices. To structure and build up a suitable information system for familiarizing the farmers with relevant and legitimate information, it is very important to understand and take care of their needs. Need is essentially a gap between "what is" (current circumstance) and "what should be" (needed circumstance).

Investigation of information needs and awareness among farmers is highly crucial to understand the farming situations at field level. Keeping that in mind, the present study was carried out at Pashu Palan Mela (Livestock Fair) held in September 2019 with the objective to:

Examine the social demographic profiles and perceptions of farmers visiting fair.

Assess the information demands among the farmers' about various agricultural and livestock disciplines.

Evaluate the significance of various sources of information to fulfill the information necessities of farmers.

\section{Materials and Methods}

The Directorate of Extension Education, GADVASU organizes two days 'Pashu Palan Mela' (livestock fair) at the university campus in the months of March and September every year. During the fair, thousands of farmers from Punjab and adjoining states visit the stalls of different departments of the university to supplement their knowledge of new technologies, innovations and information material for their benefits. The present study was conducted based on data collection from randomly selected 100 farmers of the Punjab state at September 2019 livestock fair held at GADVASU.

The respondents were interviewed with a questionnaire containing both open and close ended questions on different aspects of awareness, knowledge, seeking information demands etc. The interview schedule was prepared in vernacular (Punjabi) language to establish better communication between farmers and researchers at the time of data collection. The questionnaire was pre-tested on a few selected farmers, and the easiness of completion of the questionnaire and ambiguity of questions were noted and subsequently revised before a large-scale interview of the farmers. The data was analyzed viz. frequency and percentage with standard statistical methods (Snedecor and Cochran, 1994) to draw the results.

\section{Results and Discussion}

The study revealed that $34 \%$ of farmers belonged to age group category of up to 25 years, and $45 \%$ belonged to $26-40$ years age group, and rest $21 \%$ were of higher age groups indicating that higher number of younger farmers participated in the livestock fair (Fig. 1). The education level of most of the farmers $(64 \%)$ was up to matriculation or higher secondary, whereas merely $30 \%$ 
farmers were having a higher qualification. This may be due to the reason that acquiring the education up to higher secondary level is easier at the local level (Fig. 2). It was observed that $62 \%$ farmers in the selected respondents were small farmers with herd size up to 10 , and $34 \%$ respondents had herd size from 11-30. The average herd size was 9.6 among the farmers interviewed. In addition, majority of farmers (46\%) had 10-30 acre land followed by $37 \%$ farmers having less than 10 acre land. The average of total agricultural land under farmers surveyed was 18.37 acre (Fig. 3). Similar study has reported that majority of the farmers (42\%) lied in the age group category 26-40 years, and had their qualification from primary to higher secondary level with herd size upto 10 animals (Hundal et al., 2016).

The purpose of about $56 \%$ respondents for coming to livestock fair was to get new information on agriculture and livestock. Out of all respondents, $8 \%$ came to get mineral mixture and vaccinations/semen straws, and the purpose of $12 \%$ respondents was to know about new discoveries and inventions. The motive of $8 \%$ respondents to visit livestock fair was entertainment and pleasure, whereas $16 \%$ attended livestock fair for multiple common reasons. Moreover, approximately $33 \%$ respondents attended the fair for the first time (Table 1.). Even if new technologies are not available, about $87 \%$ people were interested to attend the livestock fair in future.

Furthermore, the percentage of farmers who enquired about breeding, animal nutrition, management practices, new technologies and other activities were $15,13,12,13$ and 4\%, respectively. In addition, $43 \%$ respondents gathered information about common multiple topics (Table 2.). Similar studies have reported that breeding and health care were priority areas for seeking information (Gupta and Tripathi, 2002; Gangil et al., 2005).
Furthermore, $99 \%$ farmers felt motivated by the awards given to progressive farmers in livestock fair. Approximately, 95\% respondents considered livestock fair as an important means for dissemination of knowledge.

The important means of information used to know about the dates of livestock fair were newspaper, television, friends, doctors, university and other common multiple modes by $53,8,31,1,1$ and $6 \%$ respondents, respectively (Table 3.). A similar study indicated that the print media was the most useful and preferred source of information about livestock fair followed by friends or fellow farmers (Rehman et al., 2011; Farooque, 2004; Ngathou et al., 2006; Gloy et al., 2000; Phipps et al., 2001; Butt, 2002; Howell and Habron, 2004; Luqman, 2004; Parthaap and Ponnusamy, 2006; Clifford and William, 2007). Moreover, it was revealed that farmers prefer to receive information from formal sources (Babu et al., 2012; Demiryurek, 2008).

In the past, newspapers have had a significant impact in the advancement of agriculture and in the wake of expanding level of literacy, the papers hold incredible potential as a source for dissemination of farm information (Lahiri and Mukhopadhyay, 2011). On the other hand, several other studies suggested that farmers prefer to assess information in casual settings from informal

and personal sources (friends, neighbors, shopkeepers) rather than formal and remotely available contacts (Wakle et al., 1998; Biradar, 2000; Edeoghon et al., 2008). The most effective information among the farmers was transferred through personal contacts and interpersonal contacts are considered as most preferred among rural communities in India (Sharma and Sahoo, 2008; Bhaskaran and Rao, 1985). 
Table.1 Distribution of respondents according to the purpose and frequency of visiting Cattle Fair

\begin{tabular}{|c|c|c|c|}
\hline S. No. & Questionnaire Items & Frequency & Percent \\
\hline A. & \multicolumn{3}{|l|}{ Purpose of visit } \\
\hline 1. & $\begin{array}{l}\text { To get new information on Agriculture and } \\
\text { Livestock }\end{array}$ & 56 & $56 \%$ \\
\hline 2. & $\begin{array}{l}\text { To get Mineral mixture and Vaccinations/Semen } \\
\text { straws }\end{array}$ & 8 & $8 \%$ \\
\hline 3. & To know about new discoveries and inventions & 12 & $12 \%$ \\
\hline 4. & For entertainment and pleasure & 8 & $8 \%$ \\
\hline 5. & For both 1. and 3. & 8 & $8 \%$ \\
\hline 6. & For both 1. and 4. & 2 & $2 \%$ \\
\hline 7. & For both 2 . and 3 . & 1 & $1 \%$ \\
\hline 8. & For both 2. and 4 & 1 & $1 \%$ \\
\hline 9. & For 1., 2. and 3. & 2 & $2 \%$ \\
\hline 10. & For 1., 2. and 4. & 1 & $1 \%$ \\
\hline 11. & For $1 ., 3$. and 4. & 1 & $1 \%$ \\
\hline B. & \multicolumn{3}{|l|}{ Frequency of visit } \\
\hline 1. & Farmers came for the first time & 33 & $33 \%$ \\
\hline 2. & Farmers used to come usually & 67 & $67 \%$ \\
\hline
\end{tabular}

Table.2 Distribution of respondents in relation to the livestock practice knowledge they received at the Pasu Palan Mela

\begin{tabular}{|c|l|c|c|}
\hline S. No. & Gain in knowledge about & Frequency & Percent \\
\hline 1. & Animal Breeding & 15 & $15 \%$ \\
\hline $\mathbf{2 .}$ & Animal Nutrition & 13 & $13 \%$ \\
\hline $\mathbf{3 .}$ & Management Practices & 12 & $12 \%$ \\
\hline $\mathbf{4 .}$ & New Technology/Machines & 13 & $13 \%$ \\
\hline $\mathbf{5 .}$ & Other & 4 & $4 \%$ \\
\hline $\mathbf{6 .}$ & Both 1. and 2. & 10 & $10 \%$ \\
\hline $\mathbf{7 .}$ & Both 1. and 3. & 8 & $8 \%$ \\
\hline $\mathbf{8 .}$ & Both 1. and 4. & 6 & $6 \%$ \\
\hline $\mathbf{9 .}$ & Both 1. and 5. & 1 & $1 \%$ \\
\hline $\mathbf{1 0 .}$ & Both 2. and 3. & 1 & $1 \%$ \\
\hline $\mathbf{1 1 .}$ & Both 2. and 4. & 1 & $1 \%$ \\
\hline $\mathbf{1 2 .}$ & Both 3. and 4. & 1 & $1 \%$ \\
\hline $\mathbf{1 3 .}$ & Both 2. and 5. & 8 & $8 \%$ \\
\hline $\mathbf{1 4 .}$ & 1., 2. and 3. & 1 & $1 \%$ \\
\hline $\mathbf{1 5 .}$ & 1., 2. and 4. & 5 & $5 \%$ \\
\hline $\mathbf{1 6 .}$ & 1., 2., 3. and 4. & & \\
\hline
\end{tabular}


Table.3 Distribution of farmers according to the sources of information utilized

\begin{tabular}{|c|l|c|c|}
\hline S. No. & Sources of information & Frequency & Percent \\
\hline $\mathbf{1 .}$ & Newspaper & 53 & $53 \%$ \\
\hline $\mathbf{2 .}$ & Television (T.V.) & 8 & $8 \%$ \\
\hline $\mathbf{3 .}$ & Friends & 31 & $31 \%$ \\
\hline $\mathbf{4 .}$ & Doctors & 1 & $1 \%$ \\
\hline $\mathbf{5 .}$ & University & 1 & $1 \%$ \\
\hline $\mathbf{6 .}$ & Newspaper and T.V. & 2 & $2 \%$ \\
\hline $\mathbf{7 .}$ & Newspaper and Friends & 3 & $3 \%$ \\
\hline $\mathbf{8 .}$ & T.V. and Friends & 1 & $1 \%$ \\
\hline
\end{tabular}

Table.4 Distribution of farmers in relation to the type of training at University they are interested to attend in future

\begin{tabular}{|c|l|c|c|}
\hline S. No. & Type of training & Frequency & Percent \\
\hline 1. & Livestock & 49 & $49 \%$ \\
\hline 2. & Agriculture & 18 & $18 \%$ \\
\hline 3. & Fisheries & 4 & $4 \%$ \\
\hline 4. & Both Agriculture and Livestock & 5 & $5 \%$ \\
\hline $\mathbf{5 .}$ & Not interested in any type of training & 24 & $24 \%$ \\
\hline
\end{tabular}

50

45

40

35

$45 \%$

30

25

20

15

$20 \%$

10

5

0

25
$2 G-1 n$

Fig.1 Distribution of respondents according to Age 


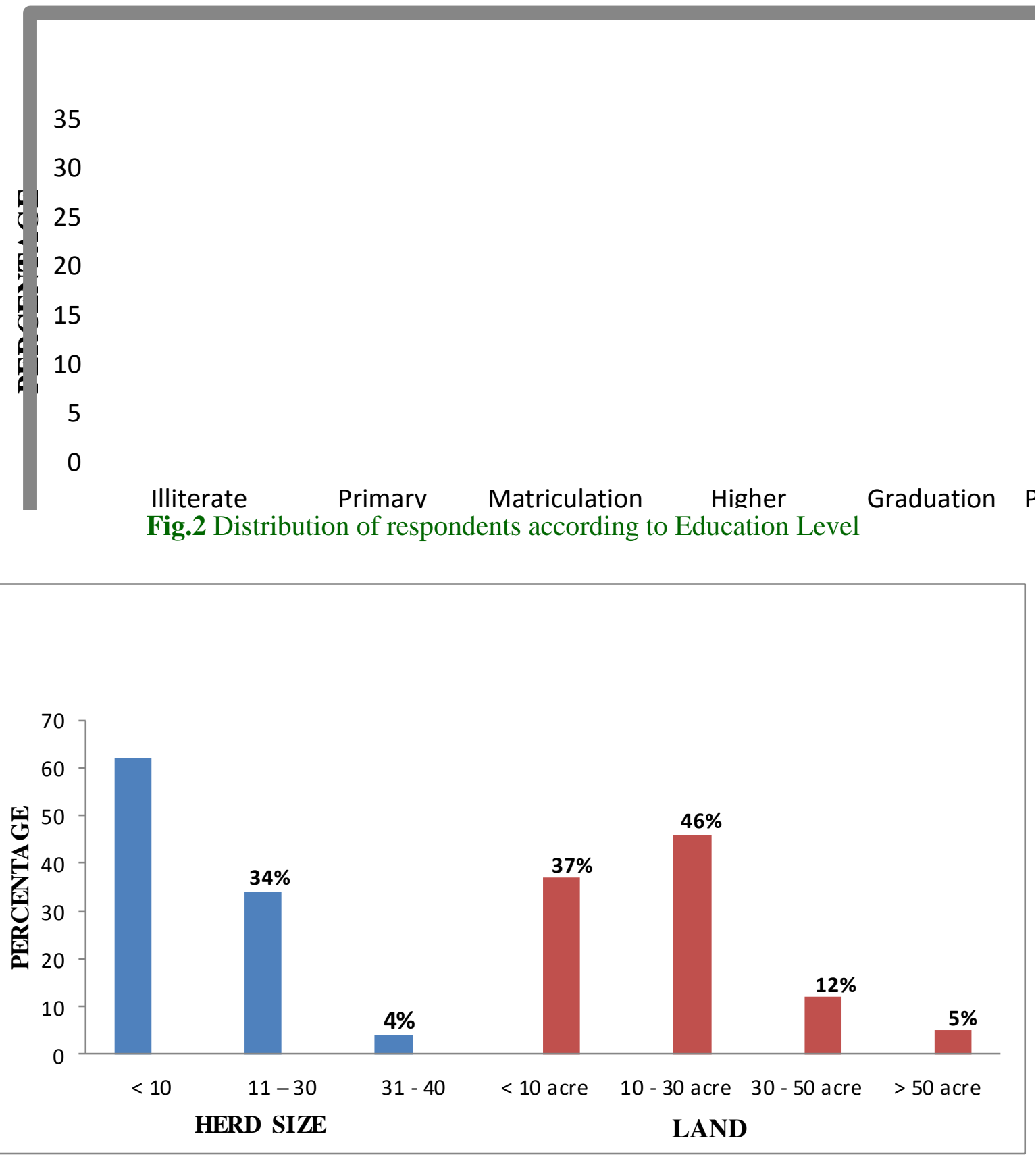

Fig.3 Distribution of respondents according to Herd size and Land owned

The technical session at the livestock fair was heard by $26.4 \%$ farmers. The respondents who opted for future trainings on livestock, agriculture, fisheries were about 49,18 and $4 \%$, respectively in contrast to $24 \%$ farmers who would not like to participate in any type of training. The farmers who would like to have training on both agriculture and livestock disciplines were about 5\% (Table 4.). Out of all the 100 surveyees, 37 farmers purchased university's recommended literature on agriculture or livestock and the livestock fair fulfilled the purpose of $86 \%$ farmers who attended it. 
Farmers have to be provided with timely and appropriate information inputs to get the maximum benefits. The motive of most of the respondents at livestock fair was to get new information on agriculture and livestock followed by new discoveries/inventions. The information demands of farmers mainly revolved around the livestock breeding followed by animal nutrition and new technologies in addition to management practices.

In addition, newspapers followed by friends were found to be the most beneficial source of disseminating knowledge for farmers. Moreover, a major chunk of farmers (58\%) were interested in livestock related disciplines as their future endeavor.

\section{References}

Adhiguru, P., Birthal, P.S. and Kumar, B.G. (2009). Strengthen pluralistic agricultural information delivery systems in India. Agric. Econ. Res. Rev. 22: 71- 79. Available at: http://ageconsearch.umn.edu/bitstream/573 82/2/5-PAdhiguru.pdf

Babu, S.C., Glendenning, C.J., Asenso-Okyere, K. and Govindarajan, S.K. (2012). Farmers' information needs and search behaviour: case study in Tamil Nadu, India. In: IFPRI discussion paper 01165, The International Food Policy Research Institute. Pp: 1-37.

Bachhav, N. (2012). Information Needs of the Rural Farmers: A Study from Maharashtra, India: A Survey. Libr. Philos. Pract. Available at: http://digitalcommons.unl.edu/libphilprac/8 66.

Bhaskaran, C. and Rao, S.M.K. (1985). Correlates of interpersonal communication behaviour of farmers in differentially progressive villages. Indian J. Ext. Educ. 18(3,4): 193221.

Biradar, B.S. (2000). Sources of information for farmer in Karnataka. Ann. Lib. Sci. Doc. 47(1): 17-22.

Butt, S.A. (2002). Role of television in the dissemination of agricultural technologies among the farmers of tehsil Faisalabad. M.Sc. (Hons.) Thesis, Deptt. of Agric. Ext., Univ. of Agric., Faisalabad, Pakistan.

Clifford, W.R. and William, E.F. (2007). Strategies for disseminating assistive technology information to farmers and ranchers. Available at: http://asae.frymulti.com/azdez.asp?$\mathrm{JID}=5 \& \mathrm{AID}=23403 \& \mathrm{CID}=\min 2007 \& \mathrm{~T}=2$.

Das, D. (2012). Sources of agricultural information among rural women: a village level study in Assam. Int. J. Econ. Res. Sept- Oct: 1-12.

Demiryurek, K., Erdem, H., Ceyhan, V., Atasever, S. and Uysal. O. (2008). Agricultural information systems and communication networks: the case of dairy farmers in the Samsun province of Turkey. Inf. Res. 13(2). http://www.informationr.net/ir/132/paper343.html

Edeoghon, C.O., Ajayi, M.T. and Ugboya, T.O. (2008). Awareness and use of sustainable agricultural practices by arable crop farmers in Ikpoba Okha local government area of Edo State. J. Sust. Dev. Agric. \& Envir. 3(2): 55-63.

Farooque, S. (2004). The present and prospective role of print media in the dissemination of agricultural information among the farmers of tehsil Tandoallahyar, district Hyderabad. M. Sc (Hons.) Thesis, Deptt. of Agric. Ext., Univ. of Agric. Faisalabad, Pakistan.

Gangil, D., Bardhan, D., Dabas, Y.P.S. and Kumar, A. (2005). Identification of training needs of livestock farmers in improved animal husbandry practices in Tarai area of Uttaranchal. Indian Dairyman 57(5): 47-49.

Gloy, B., Akridge, J. and Whipker, L. (2000). Sources of information for commercial farms: usefulness of media and personal sources. Int. Food Agribus Man. 3: 245260.

Gupta, M. and Tripathi, H. 2002. Assessment of training needs of rural women in dairy enterprise. Indian J. Dairy Sci. 55(3): 178182.

Howell, J.L. and Habron, G.B. (2004). Agricultural landowners' lack of preference for internet extension. J. Ext. 42(6). Available 
http://www.joe.org/joe/2004december/a7.sh tml.

Hundal, J.S., Sodhi, S.S., Gupta, A., Singh, J. and Chahal, U.S. (2016). Awareness, knowledge, and risks of zoonotic diseases among livestock farmers in Punjab. Vet. World 9(2): 186-191.

Lahiri, B. and Mukhopadhyay, S.D. (2011). Content Analysis of Farm Information Communicated Through Selected Newspapers. J. Glob. Commun. 4(1): 3343.

Luqman, M. (2004). A study into the effectiveness of public sector extension after decentralization in district Muzaffargarh. M.Sc. (Hons.) Thesis, Deptt. of Agric. Ext., Univ. of Agric., Faisalabad, Pakistan.

Mishra, A., Subrahmanyam, K.V., Shivarudrappa, B. and Ramakrishna, Y.S. (2006). Experiences on participatory action research for enhancing productivity of dairy animals in rainfed agro-ecosystem of India. ICRISAT 2(1): 1-14. http://ejournal.icrisat. org/agroecosystem/v2i1/v2i1experience.pdf

Ngathou, I.N., Bukenya, J.O. and Chembezi, D.M. (2006). Managing agricultural risk: Examining information sources preferred by limited resource farmers. J. Ext. 44(6). http://www.joe.org/joe/2006december/a2.shtml.

Parthaap, D.P. and Ponnusamy, K.A. (2006). Effectiveness of four mass media channels on the knowledge gain of rural women. J. Int. Agric. Ext. Edu. 13(1): 73.
Phipps, M.S., Murphy, B., Maddox, S. and Neas, K. (2001). Agriculture information preference study. Available at: http://www.ncagr.com/research

Rehman, F., Muhammad, S., Ashraf, I. and Hassan, S. (2011). Factors affecting the effectiveness of print media in the dissemination of agricultural information. Sarhad J. Agric. 27(1): 119.

Sharma, A.K. and Sahoo, K.C. (2008). Use of information sources by the farmers of Sagar District (M.P.): a survey. J. Lib. Inf. Sci. 33(1): 53-62.

Snedecor, G.W. and Cochran, W.G. (1994). Statistical methods. $7^{\text {th }}$ Edn. Oxford and IBH publications, New Delhi.

Subash, S., Gupta, J. and Babu, G. P. (2015). Information needs assessment and prioritization of dairy farmers. J. Krishi Vigyan 4(1): 51-55.

Triveni, G. (2016). A critical analysis on rate of adoption and diffusion of dairy innovations and formulation of suitable extension methodologies. PhD Thesis, P.V. Narasimha Rao Telangana Veterinary University.

Verbeke, W. (2001). The emerging role of traceability and information in demandoriented livestock production. Outlook Agr. 30(4): 249-255.

Wakle, P.K., Wattamwar, V.T. and Khalge, M.I. (1998). Utilization of different sources by farmers for seeking farm information. Maharashtra J. Ext. Educ. 17: 299-301.

\section{How to cite this article:}

Haneet Kaur, Ankita Singla, Prabhjinder Singh, Aparna, Sandip Shilwant, Snehdeep Singh and Ravneet Kaur. 2020. Profiling, Distribution and Information Needs of Farmers' Approaching Pashu Palan Melas. Int.J.Curr.Microbiol.App.Sci. 9(04): 430-437. doi: https://doi.org/10.20546/ijcmas.2020.904.052 